\title{
21
}

\section{Surface $\partial^{13} \mathrm{C}$ in Australia: A quantified measure of annual precipitation?}

\author{
Chris S.M. Turney \\ Climate Change Research Centre and School of Biological, Earth and Environmental Sciences, \\ University of New South Wales, Sydney \\ c.turney@unsw.edu.au
}

\section{Introduction}

Since the 1960s, scientific understanding of our global environment and its climate has undergone a remarkable transformation. We are now increasingly aware that the world around us is dynamic, and quasi-stable only in the short term. Recognising the challenge of human-induced climate change, the Intergovernmental Panel on Climate Change (IPCC) was established in 1988 and released its most recent Fourth Assessment Report (AR4) in 2007. The AR4 conclusions are startling: By 2100, global temperatures are estimated to increase between $1^{\circ} \mathrm{C}$ and $6.5^{\circ} \mathrm{C}$ compared with 1990 , accompanied by a sea level rise of between $0.18 \mathrm{~m}$ and $0.58 \mathrm{~m}$. This relatively large range in projections is partly due to chaotic climate variability and to uncertainties in emissions, but another significant factor is the paucity of instrumental data with which to test the estimates. A major source of concern is the extent to which the historical record captures processes representative of future change.

The above issues are of particular concern for Australia, a country distinguished by lack of water and high interannual climate variability, but with historical records extending back to only 1880 (Nicholls et al.2006). Future expectations for increasing aridity, variability and population concentration in urban and coastal areas represent a complex, uncertain and potentially dangerous challenge to Australian society, for which historical records are insufficient to capture the full range of the climate system. For instance, climate models predict that subtropical regions will expand with an increase in global temperatures (Held and Soden 2006), bringing more arid conditions to heavily populated areas (Bengtsson et al. 2006). Recent data, however, indicate expansion over the past few decades is of the same order of magnitude (5-8 of latitude) as that predicted for the end of this century (Seidel et al. 2008). This shift is associated with a reduction of ca. $20 \%$ in winter rainfall over the southwest of Western Australia, and the development of new water sources for Perth estimated to have already cost more than $\$ 500$ million (IOCI 
2002). Within the AR4, perhaps most critical of all for Australia, the future absolute amount and seasonality of rainfall across the region are highly uncertain, but seem likely to decline by the end of the current century (Christensen et al. 2007).

Past climate change provides a critical baseline against which to compare present and future warming by encompassing a broader range of extremes. Most climate reconstructions obtained from geological, chemical and biological proxies have published relationships with temperature (Mann et al. 1998, 2008; Esper et al. 2002; Moberg et al. 2005). Critically, a few measures of precipitation have been reported (e.g. Kershaw et al. 1994; Bowler 1998; Cook and van der Kaars 2006; Lough 2007; Cullen and Grierson 2009), but most are from individual sites and largely of a qualitative nature, limiting our ability to generate a long-term spatially robust reconstruction of past rainfall within Australia. One possibility for resolving this apparent impasse is the exploitation of stable isotopes in terrestrial plant material, particularly species- and tissue-specific $\partial^{13} \mathrm{C}$, an approach that has been demonstrated to provide a measure of the moisture-related conditions under which the tissues formed (e.g. Ehleringer and Cooper 1988; Farquhar et al. 1989; Turney et al. 1999, 2002). Unfortunately, few plant macrofossils (including wood) are found within terrestrial and marine sedimentary sequences across and adjacent to the mainland of Australia (D'Costa et al. 1989; Bohte and Kershaw 1999; Moss and Kershaw 2007), precluding continuous $\partial^{13} \mathrm{C}$ measurements of material through profiles. One alternative is charcoal (e.g. Ferrio et al. 2005; Turney et al. 2006).

Charcoal has considerable potential for developing long-term climate reconstructions. Firstly, charcoal is a common product from biomass burning and largely recalcitrant in lake (Kershaw 1971, 1974, 1975, 1976, 1995; Kershaw et al. 2004; Turney et al. 2004), marine (Kershaw et al. 1993; Wang et al. 1999; van der Kaars et al. 2000; Moss and Kershaw 2007) and soil (Hopkins et al. 1993; Bird et al. 1999; Lehman et al. 2008) environments, allowing preservation on geological timescales (Lynch et al.2007; Power et al.2008). Secondly, if charcoal is finely disseminated with sediments, its $\partial^{13} \mathrm{C}$ composition should reflect the proportions of $\mathrm{C} 3$ and $\mathrm{C} 4$ plants within the local vegetation (primarily controlled by the most effective season of rainfall; Hattersley 1983; Polley et al. 1993; Ehleringer et al. 1997) and/or the degree of physiological stress on $\mathrm{C} 3$ plants as a result of changing moisture availability (Ehleringer and Cooper 1988; Turney et al. 1999; Turney et al. 2002). To date, however, although $\partial^{13} \mathrm{C}$ of charcoal has been measured through selected sedimentary sequences within the Australian region (Wang et al. 1999; Turney et al. 2001), demonstrating a quantitative relationship with any moisture-related variable has proved elusive.

\section{Methods}

To test the relationship between charcoal isotopic content and moisture, surface soil samples were collected from a network of 17 sites spanning a large precipitation gradient across Australia (Figure 1 and Table 1), ranging from Buderim and Darwin at $>1500 \mathrm{~mm} /$ year, to Marla in South Australia at $<200 \mathrm{~mm} /$ year. Samples were taken down to a depth of 2 $\mathrm{cm}$ below the surface, in an attempt to provide a long-term average isotopic composition of charcoal from each site. In the laboratory, the samples were sieved through a series of meshes to isolate the fraction $2 \mathrm{~mm}$ and $125 \mu \mathrm{m}$. Using a biological microscope, individual fragments of charcoal were hand picked.

Importantly, because particulates produced during combustion are a complex mix of variably carbonised material (some of which can undergo further oxidation during diagenesis), the direct measurement of charcoal particles for $\partial^{13} \mathrm{C}$ composition is not appropriate, as incompletely carbonised material may distort the values obtained during analysis. Here, we have applied the method outlined by Bird and Gröcke (1997) for isolating oxidation resistant elemental carbon 


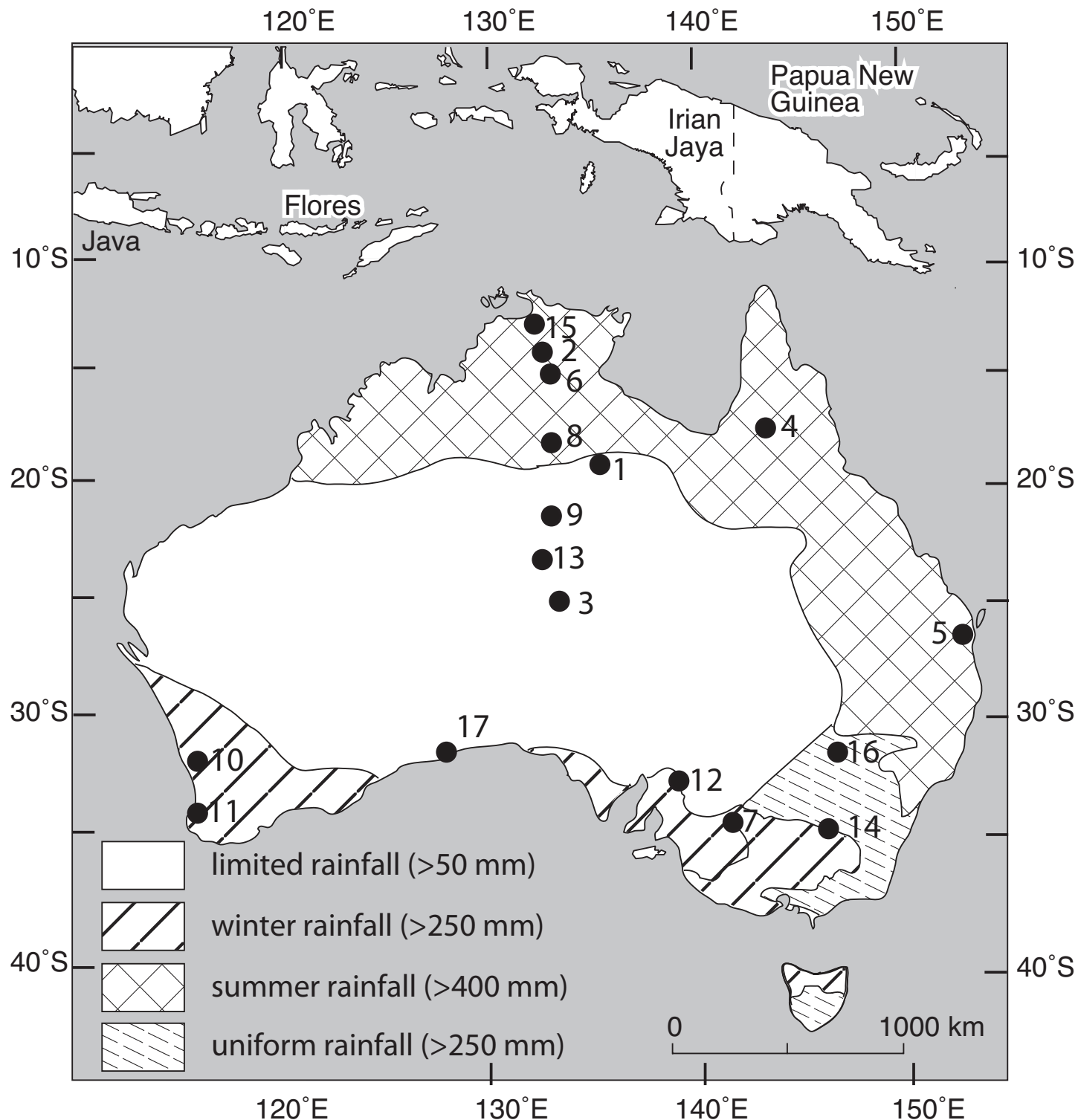

Figure 1. Surface charcoal sampling locations across Australia. Details of numbered sites are given in Table 1. Modified from Williams et al. 2009.

Table 1: Site locations, surface charcoal $\partial^{13} \mathrm{C}$ and annual mean precipitation values, with summary statistics.

\begin{tabular}{|c|c|c|c|c|c|}
\hline Site number & Site name & Latitude, 'S & Longitude, ${ }^{\circ} \mathbf{E}$ & $\partial^{13} \mathrm{C}, \% 00$ (VPDB) & $\begin{array}{l}\text { Annual } \\
\text { precipitation, mm }\end{array}$ \\
\hline 1 & Barkly Station & $19^{\circ} 42^{\prime \prime}$ & $135^{\circ} 49^{\prime \prime}$ & -23.1 & 332 \\
\hline 2 & Pine Creek & $13^{\circ} 49^{\prime \prime}$ & $131^{\circ} 49^{\prime \prime}$ & -27.5 & 1178 \\
\hline 3 & Marla & $27^{\circ} 08^{\prime \prime}$ & $133^{\circ} 30^{\prime \prime}$ & -24.9 & 190 \\
\hline 4 & Mount Garnet & $17^{\circ} 47^{\prime \prime}$ & $144^{\circ} 57^{\prime \prime}$ & -25.4 & 759 \\
\hline 5 & Buderim & $26^{\circ} 42^{\prime \prime}$ & $153^{\circ} 04^{\prime \prime}$ & -26.6 & 1712 \\
\hline 6 & Mataranka & $14^{\circ} 56^{\prime \prime}$ & $133^{\circ} 04^{\prime \prime}$ & -25.2 & 800 \\
\hline 7 & Renmark & $34^{\circ} 14^{\prime \prime}$ & $140^{\circ} 37^{\prime \prime}$ & -23.1 & 257 \\
\hline 8 & Renner & $18^{\circ} 19^{\prime \prime}$ & $133^{\circ} 47^{\prime \prime}$ & -24.7 & 407 \\
\hline 9 & Ti Tree & $22^{\circ} 07^{\prime \prime}$ & $133^{\circ} 25^{\prime \prime}$ & -22.6 & 299 \\
\hline 10 & Freemantle & $32^{\circ} 02^{\prime \prime}$ & $115^{\circ} 45^{\prime \prime}$ & -25.2 & 838 \\
\hline 11 & Margaret River & $34^{\circ} 09^{\prime \prime}$ & $115^{\circ} 02^{\prime \prime}$ & -25.8 & 1163 \\
\hline 12 & Pt Augusta & $32^{\circ} 28^{\prime \prime}$ & $137^{\circ} 44^{\prime \prime}$ & -24.7 & 241 \\
\hline
\end{tabular}


Table 1: Continued

\begin{tabular}{|c|c|c|c|c|c|}
\hline Site number & Site name & Latitude, 's & Longitude, ${ }^{\circ} \mathbf{E}$ & $\partial^{13} \mathrm{C}, \% 0$ (VPDB) & $\begin{array}{l}\text { Annual } \\
\text { precipitation, mm }\end{array}$ \\
\hline 13 & Erlunda & $25^{\circ} 11^{\prime \prime}$ & $133^{\circ} 12^{\prime \prime}$ & -23.6 & 203 \\
\hline 14 & Dubbo & $32^{\circ} 26^{\prime \prime}$ & $148^{\circ} 21^{\prime \prime}$ & -25.6 & 590 \\
\hline 15 & Darwin & $12^{\circ} 40^{\prime \prime}$ & $131^{\circ} 04^{\prime \prime}$ & -26.5 & 1521 \\
\hline 16 & Goondawindi & $28^{\circ} 44^{\prime \prime}$ & $150^{\circ} 16^{\prime \prime}$ & -24.0 & 577 \\
\hline \multirow[t]{5}{*}{17} & Allan's Cave & $31^{\circ} 36^{\prime \prime}$ & $129^{\circ} 06^{\prime \prime}$ & -25.5 & 248 \\
\hline & & & & Statistics & \\
\hline & & & & $R^{2}\left(R_{a d j}^{2}\right)$ & $0.57(0.54)$ \\
\hline & & & & F value & 20.01 \\
\hline & & & & $P$ value & 0.0004469 \\
\hline
\end{tabular}

(OREC). Elemental carbon is defined here as carbon that survives the chemical isolation procedure outlined below.

Charcoal samples extracted from between $2 \mathrm{~mm}$ and $125 \mu \mathrm{m}$ were decarbonated overnight using $1 \mathrm{~N} \mathrm{HCl}$, washed with $\mathrm{Milli}^{\mathrm{TM}}$ water, centrifuged and then placed in concentrated $\mathrm{HF}$ overnight at $60^{\circ} \mathrm{C}$ to remove silicate material. The remaining material was then washed again in MilliQ ${ }^{\mathrm{TM}}$ water, centrifuged and placed in $0.1 \mathrm{~N} \mathrm{NaOH}$ for three hours at room temperature to remove humic acids. Samples were then washed repeatedly in MilliQ ${ }^{\mathrm{TM}}$ water, until the solution became clear, and placed in a $\mathrm{K}_{2} \mathrm{Cr}_{2} \mathrm{O}_{7} / \mathrm{H}_{2} \mathrm{SO}_{4}$ solution at $60^{\circ} \mathrm{C}$ for 14 hours (Bird and Gröcke 1997). The OREC samples were again washed with MilliQ ${ }^{\mathrm{TM}}$ water, then freezedried.

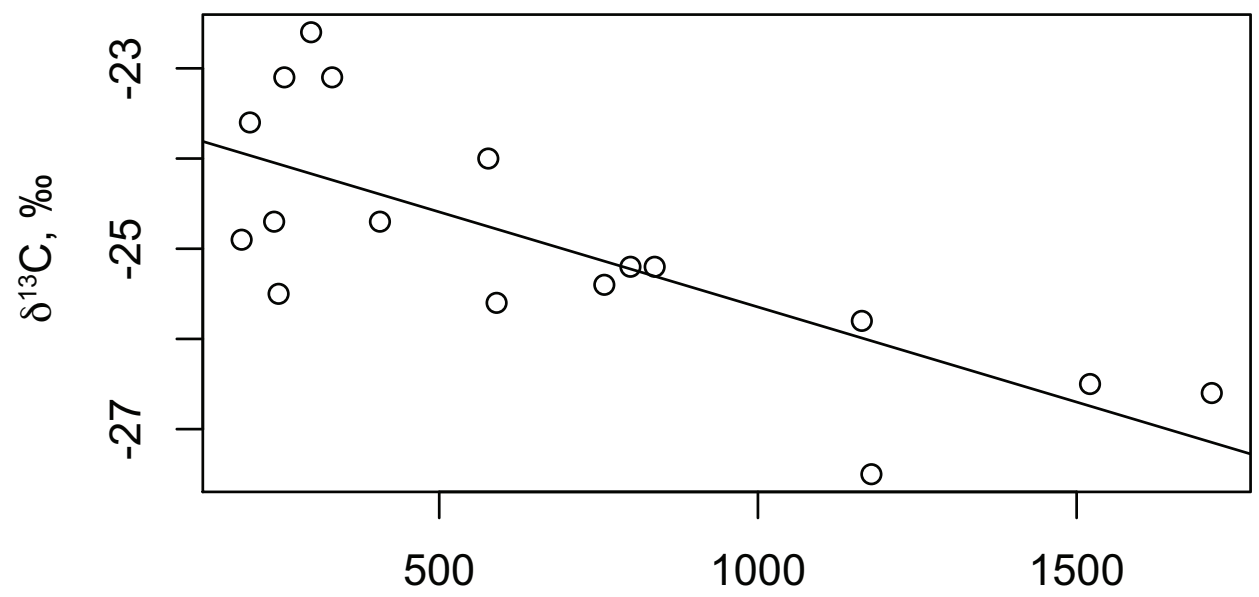

Annual precipitation, $\mathrm{mm}$

Figure 2. Relationship between surface charcoal $\partial^{13} \mathrm{C}$ and annual precipitation in Australia.

The stable carbon isotope $\left(\partial^{13} \mathrm{C}\right)$ composition of OREC samples was determined using an elemental analyser coupled to a Micromass Prism III mass spectrometer operated in continuous flow mode. $\partial^{13} \mathrm{C}$ values are expressed as per mille (\%0) relative to the international V-PDB standard, with a precision of $0.15 \%$ at $1 \sigma$. Duplicate measurements were made and an average value taken. 


\section{Results and discussion}

The isotopic values obtained during this study range from $-23.1 \%$ at Renmark in the arid interior of Victoria, to $-27.5 \% 0$ at Pine Creek in the tropical Northern Territory (Table 1). Overall, there appears to be a general trend to heavier values in the interior of Australia (Figure 1). Assuming the carbonised plant material from the surface soil samples reflects local vegetation, the OREC $\partial^{13} \mathrm{C}$ values can be used for comparison against long-term climate data.

Typical $\mathrm{C} 3$ and $\mathrm{C} 4 \partial^{13} \mathrm{C}$ values range from -22 to $-33 \%$, and -9 to $-16 \%$ respectively (Deines 1980). The results obtained fall almost entirely within the range of values expected for $\mathrm{C} 3$ vegetation and suggest little (if any) carbon derived from $\mathrm{C} 4$ photosynthesis is present in the OREC samples collected across Australia. If correct, the enriched ${ }^{13} \mathrm{C}$ values are typical of C3 plants in moisture-limited environmental conditions (Ehleringer and Cooper 1988; Turney et al. 1999), as a result of reduced stomatal conductance and/or altered net assimilation.

To test the relationship between OREC $\partial^{13} \mathrm{C}$ values and climate, data were compared with bioclimate estimates obtained from each site generated from the prediction system BIOCLIM (Busby 1991). BIOCLIM produces up to 35 bioclimatic parameters based on long-term climate measurements of maximum and minimum temperature, rainfall, solar radiation and pan evaporation. Comparisons were made with all parameters. Although several of the climate variables proved highly correlated with surface charcoal OREC $\partial^{13} \mathrm{C}$ values, the most robust and significant relationship was that obtained against annual precipitation across a range of 260 $\mathrm{mm}$ to $1200 \mathrm{~mm}$ (Figure 2 and Table 1 ).

We observe a linear and negative correlation between annual precipitation and OREC $\partial^{13} \mathrm{C}$ (Figure 2) $(\mathrm{F}=20.01, \mathrm{p}<0.0004469)$, explaining more than half of the variance $\left(\mathrm{R}^{2}=\right.$ $\left.0.57, \mathrm{R}_{\text {adj }}^{2}=0.54\right)$. The correlation is highly significant, suggesting that the $\partial^{13} \mathrm{C}$ in vegetation of the immediate area (as represented by the surface soil charcoal) is strongly influenced by the amount of rainfall over the year. This result is consistent with previous studies, which have identified the importance of moisture availability in controlling stomatal conductance (Ehleringer and Cooper 1988) and the composition of individual Australian species (Miller et al. 2001) in the Queensland plant community $\partial^{13} \mathrm{C}$ (Stewart et al. 1995). For instance, over a $1100 \mathrm{~mm}$ annual rainfall range, the Queensland study demonstrated a mean 4\%o shift (Stewart et al. 1995), comparable to the mean 3\%o difference observed in the charcoal samples collected across Australia (Figure 2).

The mechanism for the changes in ${ }^{13} \mathrm{C}$ may be best explained by stomatal conductance responses to moisture availability. During growth, under low moisture availability, plant stomatal conductance will decrease to minimise water loss, reducing the exchange of carbon dioxide between the substomatal cavity and the surrounding atmosphere, thereby decreasing the discrimination against ${ }^{13} \mathrm{C}$ relative to ${ }^{12} \mathrm{C}$ (Farquhar et al. 1989). The preliminary results reported here, therefore, provide strong support that charcoal $\partial^{13} \mathrm{C}$ may offer considerable potential for quantifying past changes in precipitation, and suggest the observation made within community-averaged $\partial^{13} \mathrm{C}$ observed across a rainfall gradient in Queensland (Stewart et al. 1995) may be extended to the fossil record.

The above relationship should only be considered a first-order estimate, however. During heating, the cellulose and hemicellulose content of plant material form mainly volatile products due to the thermal cleavage of sugar units, while lignin dominates the production of charcoal since it is not so easily cleaved to lower-molecular-weight fragments. As a result, during carbonisation of woody material, increasing temperature progressively depletes the ${ }^{13} \mathrm{C}$ content of bulk charcoal by up to $1.3 \%$ (Turney et al.2006), consistent with the greater susceptibility of cellulose to thermal degradation relative to lignin (Czimczik et al.2002). Although the OREC 
is most likely dominated by lignin (Bird and Gröcke 1997), it is unclear whether the isotopic fractionation observed in bulk charcoal reflects an increasing proportion of this component in the final char and/or there is a genuine fractionation within lignin with changing temperature. Another potentially significant limitation of this study is the uncertain age range of the charcoal obtained from the surface soil samples. Although the sampling strategy adopted here had the advantage of providing an average estimate of surface vegetation ${ }^{13} \mathrm{C}$ values, the duration represented is unknown and may be of the order of centuries. Remarkably, in spite of these issues, there still remains a statistically significant correlation between isotopic content and climate, suggesting that if samples were obtained over the same period as meteorological data, a more robust relationship may be quantified.

\section{Conclusions}

There is a statistically significant relationship between elemental carbon ${ }^{13} \mathrm{C}$ obtained from 'modern' surface charcoal and annual precipitation in Australia. Such a relationship is expected because of the important role moisture availability plays in the distribution and response of flora. In spite of the uncertainties associated with comparing climate parameters derived from historic meteorological data and surface charcoal of unknown age, the relationship suggests this approach might be used to quantify past changes in rainfall across Australia. Future studies focusing on comparing charcoal samples of known age with meteorological data over a common period should improve the robustness of future reconstructions. This finding is of particular importance in Australia, a country distinguished by lack of water and where few quantified methods of precipitation are available to extend historical records beyond 1880 .

\section{Acknowledgements}

I would like to thank Peter for all his help and encouragement over the years. I've been extremely privileged to work with Peter and have hugely benefited from our collaboration. It's been an absolute pleasure and I feel sure I've gained far more from working with him than he has from me! This work was made possible thanks to the support of the Australian Research Council through a QEII and Laureate Fellowship. Many thanks to Joan Cowley at the Research School of Earth Sciences who kindly helped with the isotopic analysis of the samples and Nick Porch who extracted the BIOCLIM data for me. Thanks also to Mike Smith and Charlie Dortch who kindly provided samples from the Nullarbor Plain and southwest Australia respectively. Michael Bird and one anonymous reviewer kindly helped improve the text.

\section{References}

Bengtsson, L., Hodges, K.I. and Roeckner, E. 2006. Storm tracks and climate change. Journal of Climate 19:3518-3543.

Bird, M.I. and Gröcke, D.R. 1997. Determination of the abundance and carbon-isotope composition of elemental carbon in sediments. Geochimica et Cosmochimica Acta 61:3413-3423.

Bird, M.I., Moyo, C., Veenendaal, E.M., Lloyd, J. and Frost, P. 1999. Stability of elemental carbon in a savanna soil. Global Biogeochemical Cycles 13:923-932.

Bohte, A. and Kershaw, A.P. 1999. Taphonomic influences on the interpretation of the palaeoecological record from Lynch's Crater, northeastern Australia. Quaternary International 57/58:49-59. 
Bowler,J.M. 1998. Willandra Lakes revisited: environmental framework for human occupation. Archaeology in Oceania 33:120-155.

Busby,J.R. 1991. BIOCLIM - a bioclimatic analysis prediction system. In: Margules, C.R. and Austin, M.P. (eds), Nature Conservation: Cost Effective Biological Surveys and Data Analysis. CSIRO, Melbourne, pp. 64-68.

Christensen, J.H., Hewitson, B., Busuioc, A., Chen, A., Gao, X., Held, I., Jones, R., Kolli, R.K., Kwon, W.-T., Laprise, R., Magaña Rueda, R., Mearns, L., Menéndez, C.G., Räisänen, J. Rinke, A., Sarr, A. and Whetton, P. 2007. Regional Climate Projections. In: Solomon, S., Qin, D., Manning, M., Chen, Z., Marquis, M., Averyt, K.B., Tignor, M. and Miller, H.L. (eds) 2007. Climate Change 2007: The Physical Science Basis. Contribution of Working Group I to the Fourth Assessment Report of the Intergovernmental Panel on Climate Change. Cambridge University Press, Cambridge, UK.

Cook, E.J. and van der Kaars, S. 2006. Development and testing of transfer functions for generating quantitative climatic estimates from Australian pollen data.Journal of Quaternary Science 21:723-733.

Cullen, L.E. and Grierson, P.F. 2009. Multi-decadal scale variability in autumn-winter rainfall in south-western Australia since $1655 \mathrm{AD}$ as reconstructed from tree rings of Callitris columellaris. Climate Dynamics 33:433-444.

Czimczik, C.I., Preston, C.M., Schmidt, M.W.I., Werner, R.A. and Schulze, E.-D. 2002. Effects of charring on mass, organic carbon, and stable carbon isotope composition of wood. Organic Geochemistry 33:1207-1223.

D’Costa, D.M., Edney, P., Kershaw, A.P., de Deckker, P. 1989. Late Quaternary palaeoecology of Tower Hill, Victoria, Australia. Journal of Biogeography 16:461-482.

Deines, P. 1980. The isotopic composition of reduced organic carbon. In: Fritz, P. and Fontes, J.Ch. (eds), Handbook of Environmental Isotope Geochemistry 1A. Elsevier, Amsterdam, 329-406.

Ehleringer, J.R., Cerling, T.E. and Helliker, B.R. 1997. C4 photosynthesis, atmospheric CO2 and climate. Oecologia 112:285-299.

Ehleringer, J.R. and Cooper, T.A. 1988. Correlations between carbon isotope ratio and microhabitat in desert plants. Oecologia 76:562-566.

Esper, J., Cook, E.R. and Schweingruber, F.H. 2002. Low-frequency signals in long tree-ring chronologies for reconstructing past temperature variability. Science 295:2250-2253.

Farquhar, G.D., Ehleringer, J.R. and Hubick, K.T. 1989. Carbon isotope discrimination and photosynthesis. Annual Review of Plant Physiology and Plant Molecular Biology 40:503-537.

Ferrio, J.P., Araus, J.L., Buxó, R., Voltas, J. and Bort, J. 2005. Water management practices and climate in ancient agriculture: inferences from the stable isotope composition of archaeobotanical remains. Vegetation History and Archaeobotany 14:510-517.

Hattersley, P.W. 1983. The distribution of C3 and C4 grasses in Australia in relation to climate. Oecologia 57:113-128.

Held, I.M. and Soden, B.J. 2006. Robust responses of the hydrological cycle to global warming. Journal of Climate 19:5686-5699.

Hopkins, M.S., Ash, J., Graham, A.W., Head, J. and Hewett, R.K. 1993. Charcoal evidence of the spatial extent of the Eucalyptus woodland expansions and rainforest contractions in North Queensland during the late Pleistocene. Journal of Biogeography 20:357-372.

IOCI. 2002. Climate variability and change in south west Western Australia. Indian Ocean Climate Initiative Panel, c/o Department of the Environment, Water and Catchment Protection, Hyatt Place, 3 Plain St, East Perth, WA, 6004.

Kershaw, A.P. 1971. A pollen diagram from Quincan Crater, north-east Queensland, Australia. New Phytologist 70:669-681. 
Kershaw, A.P. 1974. A long continuous pollen sequence from north-eastern Australia. Nature 251:222-223.

Kershaw, A.P. 1975. Stratigraphy and pollen analysis of Bromfield Swamp, North Eastern Queensland, Australia. Nerw Phytologist 75:173-191.

Kershaw, A.P. 1976. A late Pleistocene and Holocene pollen diagram from Lynch's Crater, north-eastern Queensland, Australia. Nerw Phytologist 77:469-498.

Kershaw, A.P. 1995. Environmental change in Greater Australia. Antiquity 69:656-675.

Kershaw, A.P., McKenzie, G.M. and McMinn, A. 1993. A Quaternary vegetation history of northeastern Queensland from pollen analysis of ODP site 820. Proceedings of the Ocean Drilling Program, Scientific Results 133:107-114.

Kershaw, A.P., Bulman, D. and Busby,J.R. 1994. An examination of modern and pre-European settlement pollen samples from southeastern Australia - assessment of their application to quantitative reconstruction of past vegetation and climate. Review of Palaeobotany and Palynology 82:83-96.

Kershaw, A.P., D'Costa, D.M., Tibby, J., Wagstaff, B.E. and Heijnis, H. 2004. The last million years around Lake Keilambete, western Victoria. Proceedings, Royal Society of Victoria 116:95-106.

Lehman, J., Skjemstad, J., Sohi, S., Carter,J., Barson, M., Falloon, P., Coleman, K., Woodbury, P. and Krull, E. 2008. Australian climate-carbon cycle feedback reduced by soil black carbon. Nature Geoscience 1:832-835.

Lough, J.M. 2007. Tropical river flow and rainfall reconstructions from coral luminescence: Great Barrier Reef. Paleoceanography 22:doi:10.1029/2006PA001377.

Lynch, A.H., Beringer,J., Kershaw, P., Marshall, A., Mooney, S., Tapper, N., Turney, C. and van der Kaars, S. 2007. The scope for the palaeorecords to evaluate climate and fire interactions in Australia. Annual Review of Earth and Planetary Sciences 35:215-239.

Mann, M.E., Bradley, R.S. and Hughes, M.K. 1998. Global-scale temperature patterns and climate forcing over the past six centuries. Nature 392:779-787.

Mann, M.E., Zhang, Z., Hughes, M.K., Bradley, R.S., Miller, S.K., Rutherford, S. and Ni., F. 2008. Proxy-based reconstructions of hemispheric and global surface temperature variations over the past two millennia. Proceedings of the National Academy of Sciences 105:13252-13257.

Miller, J.M., Williams, R.J. and Farquhar, G.D. 2001. Carbon isotope discrimination by a sequence of Eucalyptus species along a subcontinental rainfall gradient in Australia. Functional Ecology 15:222-232.

Moberg, A., Sonechkin, D.M., Holmgren, K., Datsenko, N.M. and Karlén, W. 2005. Highly variable Northern Hemisphere temperatures reconstructed from low- and high-resolution proxy data. Nature 433:613-617.

Moss, P.T. and Kershaw, A.P. 2007. A late Quaternary marine palynological record (oxygen isotope stages 1 to 7) for the humid tropics of northeastern Australia based on ODP Site 820. Palaeogeography, Palaeoclimatology, Palaeoecology 251:4-22.

Nicholls, N., Collins, D., Trewin, B. and Hope, P. 2006. Historical instrumental climate data for Australia - Quality and utility for palaeoclimatic studies. Journal of Quaternary Science 21:681-688.

Polley, H.W., Johnson, H.B., Marino, B.D. and Mayeux, H.S. 1993. Increase in C3 plant wateruse efficiency and biomass over glacial to present $\mathrm{CO} 2$ concentrations. Nature 361:61-64.

Power, M.J., Marlon, J., Ortiz, N., Bartlein, P.J., Harrison, S.P., Mayle, F.E., Ballouche, A., Bradshaw, R.H.W., Carcaillet, C., Cordova, C., Mooney, S., Moreno, P.L., Prentice, I.C., Thonicke, K., Tinner, W., Whitlock, C., Zhang, Y., Zhao, Y., Ali, A.A., Anderson, R.S., Beer, R., Behling, H., Briles, C., Brown, K.J., Brunelle, A., Bush, M., Camill, P., 
Chu, G.Q. Clark, J., Colombaroli, D., Connor, S., Daniau, A.-L., Daniels, M., Dodson, J., Doughty, E., Edwards, M.E., Finsinger, W., Foster, D., Frechette, J., Gaillard, M.-J., Gavin, D.G., Gobet, E., Haberle, S., Hallett, D.J., Higuera, P., Hope, G., Horn, S., Inoue, J., Kaltenrieder, P., Kennedy, L., Kong, Z.C., Larsen, C., Long, C.J., Lynch, J., Lynch, E.A., McGlone, M., Meeks, S., Mensing, S., Meyer, G., Minckley, T., Mohr, J., Nelson, D.M., New, J., Newnham, R., Noti, R., Oswald, W., Pierce, J., Richard, P.J.H., Rowe, C., Sanchez Goñi, M.F., Shuman, B.N., Takahara, H., Toney, J., Turney, C., Urrego-Sanchez, D.H., Umbanhowar, C., Vandergoes, M., Vanniere, B., Vescovi, E., Walsh, M., Wang, X., Williams, N., Wilmshurst, J. and Zhang, J.H. 2008. Changes in fire regimes since the Last Glacial Maximum: an assessment based on a global synthesis and analysis of charcoal data. In: Climate Dynamics. pp. 887-907.

Seidel, D.J., Fu, Q. Randel, W.J. and Reichler, T.J. 2008. Widening of the tropical belt in a changing climate nature. Nature Geoscience 1:21-24.

Stewart, G.R., Turnbull, M.H., Schmidt, S. and Erskine, P.D. 1995. 13C natural abundance in plant communities along a rainfall gradient: a biological integrator of water availability. Australian Journal of Plant Physiology 22:51-55.

Turney, C.S.M., Barringer, J., Hunt, J.E. and McGlone, M.S. 1999. Estimating past leaf-to-air vapour pressure deficit from terrestrial plant 213C. Journal of Quaternary Science 14:437-442.

Turney, C.S.M., Bird, M.I. and Roberts, R.G. 2001. Elemental $\partial 13 \mathrm{C}$ at Allen's Cave, Nullarbor Plain, Australia: Assessing post-depositional disturbance and reconstructing past environments. Journal of Quaternary Science 16:779-784.

Turney, C.S.M., Hunt, J.E. and Burrows, C. 2002. Deriving a consistent $\partial 13 \mathrm{C}$ signature from tree canopy leaf material: implications for palaeoclimatic reconstruction. New Phytologist 155:301-311.

Turney, C.S.M., Kershaw, A.P., Clemens, S.C., Branch, N., Moss, P.T. and Fifield, L.K. 2004. Millennial and orbital variations of El Niño/Southern Oscillation and high-latitude climate in the last glacial period. Nature 428:306-310.

Turney, C.S.M., Wheeler, D. and Chivas, A.R. 2006. Carbon isotope fractionation in wood during carbonization. Geochimica et Cosmochimica Acta 70:960-964.

van der Kaars, S., Wang, X., Kershaw, P., Guichard, F. and Setiabudi, A. 2000. Late Quaternary palaeoecological record from the Banda Sea, Indonesia: Patterns of vegetation, climate and biomass burning in Indonesia and northern Australia. Palaeogeography, Palaeoclimatology, Palaeoecology 155:135-153.

Wang, X., van der Kaars, S., Kershaw, P., Bird, M. and Jansen, F.1999. A record of fire, vegetation and climate through the last three glacial cycles from Lombok Ridge core G6-4, eastern Indian Ocean, Indonesia. Palaeogeography, Palaeoclimatology, Palaeoecology 147:241-256.

Williams, M., Cook, E., van der Kaars, S., Barrows, T., Shulmeister, J. and Kershaw, P. 2009. Glacial and deglacial climatic patterns in Australia and surrounding regions from 35000 to 10000 years ago reconstructed from terrestrial and near-shore proxy data. Quaternary Science Reviews 28:2398-2419. 